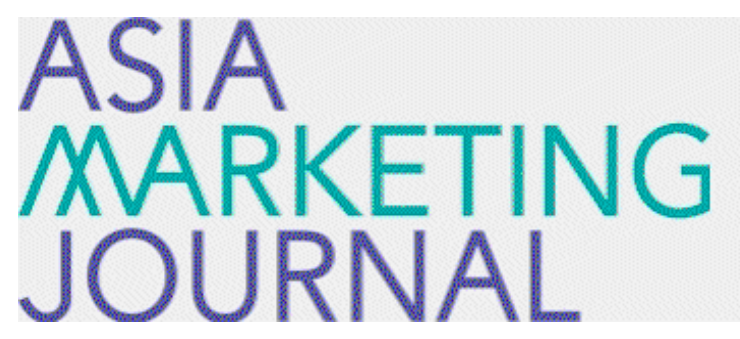

ASIA MARKETING JOURNAL

Volume 13 | Issue 3

Article 11

10-30-2011

\title{
신한카드 브랜드구축을 위한 IMC전략
}

Kwang Ho Ahn

Chang Jo Yoo

Woon Yong Park

Follow this and additional works at: https://amj.kma.re.kr/journal

Part of the Marketing Commons

\section{Recommended Citation}

Ahn, Kwang Ho; Yoo, Chang Jo; and Park, Woon Yong (2011) "신한카드 브랜드구축을 위한 IMC전략," Asia Marketing Journal: Vol. 13 : Iss. 3 , Article 11.

Available at: https://doi.org/10.53728/2765-6500.1295

This Article is brought to you for free and open access by Asia Marketing Journal. It has been accepted for inclusion in Asia Marketing Journal by an authorized editor of Asia Marketing Journal. 


\title{
신한카드 브랜드구축을 위한 IMC전략
}

\section{IMC Strategy of Sinhan Card for Building the Strong Brand Equity}

\author{
안 광 호 $(\mathrm{Ahn}, \mathrm{Kwang} \mathrm{Ho})^{*}$ \\ 유 창 조(Yoo, Chang $\mathrm{Jo}^{* * *}$ \\ 박 운 용(Park, Woon Yong)***
}

성숙기에 들어선 대부분의 제품시장에서 경쟁제품들 간에 제품속성에서의 차이가 갈수록 줄어듦에 따라 많은 기업들이 브랜드이미지에서의 차별화를 지속적 경쟁우위의 주요원천으로 인식하고 있다.

이제 소비자는 단순히 상품을 구매하는 것이 아니라 높은 인지도와 차별화된 이미지를 가진 파워 브랜드를 구매한다. 강력한 브랜드는 고려대상 상표군(consideration set)에 우선적으로 포함되고 높 은 고객충성도와 매출을 실현하는데 기여한다. 브랜드파워의 구축은 체계적인 브랜드관리시스템을 토 대로 브랜드자산을 창출하고 지속적인 마케팅투자를 통해 이를 강화시키는 것에서 비롯된다.

2007년 LG카드를 인수한 신한카드는 새로운 브랜드컨셉트를 기반으로 매년 새로운 주제의 광고캠 페인 도입과 다양한 마케팅커뮤니케이션 도구들을 효과적으로 결합함으로써 높은 브랜드 인지도와 차별적 브랜드이미지를 구축하는데 성공했다.

본 사례에서는 경쟁이 치열한 신용카드시장에서 신한카드가 새로운 브랜드 아이덴티티를 정립하고 지속적이고 체계적인 IMC전략을 통해 강력한 브랜드자산을 창출함으로써 신용카드 업계에서 시장선 도브랜드의 지위를 구축한 과정에 대해 자세히 살펴본다.

핵심개념: 브랜드인지도, 브랜드이미지, 브랜드자산, 고객자산, IMC

\section{I. 서 론}

오늘날 전세계의 많은 기업들이 브랜드를 귀
중한 무형자산으로 인식하고 있으며, 이에 따라 브랜드자산 구축을 위해 많은 노력을 기울이고 있다. 이러한 노력을 기울이는 이유들 중 하나 는 성숙기에 들어선 대부분의 소비용품시장에
인하대학교 경영대학 경영학부 교수(ahnkh@inha.ac.kr)

** 동국대학교 경영대학 경영학부 교수(yoo@dongguk.edu)

*** 인하대학교 경영대학 경영학부 박사(p7w28@hanmail.net) 
서 상표들간의 평준화로 인하여 경쟁상표들 간 에 제품품질의 차이가 갈수록 줄어들고 있기 때문이다(안광호, 하영원, 박흥수, 2010). 브랜 드자산(brand equity)이란 어떤 제품이나 서비 스가 브랜드를 가졌기 때문에 발생된 바람직한 마케팅효과(가령, 높은 상표애호도, 시장점유율 또는 수익)인데(Keller, 1992), 높은 브랜드자산 이 소비자 선택행동에 미치는 효과는 우리의 일상생활에서 잘 나타나고 있다. 아침에 일어나 죽염치약으로 이를 닦고 엘라스틴으로 머리를 감고 도브 비누로 세수를 하고 조선일보를 보 며 트로피카나 오렌지 주스를 한 잔 마시고 풀 무원 두부를 넣은 된장찌개를 곁들여 이천미 로 지은 아침식사를 하고는 폴로셔츠에 갭 면 바지를 입고 출근하듯 우리는 수많은 유명브 랜드에 둘러싸여 생활하고 있다. Coca Cola, Intel, BMW, Starbucks, Gillette 등은 해당제품 영역에서 최고의 브랜드임을 누구도 의심하지 않는다(안광호, 2003). 따라서 이제 소비자는 상 품을 구매하는 것이 아니라 높은 인지도와 차 별화된 이미지를 가진 파워브랜드를 구매한다. 파워브랜드는 고려대상 상표군(consideration set) 에 우선적으로 포함되는 이점(Prakash, 1990)이 있기 때문에 높은 매출과 시장점유율을 차지한 다. 이러한 파워브랜드들의 강력한 힘은 체계적 인 브랜드관리시스템을 토대로 브랜드자산을 창출하고 지속적인 마케팅투자를 통해 창출된 브랜드자산을 지속, 강화 시키는 것에서 비롯된 다(안광호, 2003).

이하에서는 경쟁이 치열한 카드시장에서 2007 년 신한카드가 LG카드를 인수한 후 새로운 브 랜드아이덴티티를 정립하고 지속적이고 체계적 인IMC전략을 통해 강력한 브랜드자산을 창출
함으로써 신용카드 업계에서 시장선도브랜드의 지위를 구축한 과정에 대해 소개하기로 한다

\section{II. 신한카드의 브랜드구축을 위한 $\mathrm{IMC}$ 전략}

브랜드자산을 구축하기 위해 기업은 좋은 제 품을 만드는 것뿐 아니라 마케팅케뮤니케이션 활동을 통해 타겟소비자의 마음속에 차별적 이 미지를 형성/강화해야 한다(안광호, 하영원, 박 흥수, 2010). 아무리 우수한 상품을 개발했다 하더라도 소비자에게 상품의 우월성을 각인시 키지 못한다면 그 기업은 시장에서 성공을 거 두지 못할 것이다. 신한카드는 차별적 브랜드컨 셉트를 개발하고 고객들의 모든 브랜드 접점들 과 가용매체의 통합적 관리를 통해 브랜드컨셉 트를 일관성있게 전달하는 IMC전략을 개발/실 행함으로써 브랜드파워를 구축하는데 성공했다.

LG카드를 인수한 신한카드는 새로운 브랜드 컨셉트를 기반으로 매년 새로운 주제의 광고캠 페인을 지속적으로 도입함으로써 높은 브랜드 인지도와 차별적 브랜드이미지를 구축하고자 했다. 기억하기 쉬운 메시지, 일상에서 접할 수 있는 사용상황, 그리고 “고객님 덕분이죠”, “좋 아요” 등의 리듬감 있는 문구 등의 효과적 결 합을 통해 타겟고객의 마음속에 신한카드에 대 한 긍정적이고 강력하면서 차별적 이미지를 심 는데 주력하였다. 소비자들이 제품을 구입할 때 머리속에 떠올리는 상표대안들의 집합인 고려 상표군에 포함되는 브랜드의 평균 숫자가 3-5 개 정도(Silk and Urban, 1978)임을 감안 할 
때 반복적이고 지속적인 광고메시지노출을 통 해 높은 브랜드 친숙성을 구축하는 것은 파워 브랜드가 되는데 핵심 성공요인이다.

신한카드는 지난 몇 년간 다양한 상품과 소비 자혜택을 개발하고 체계적이고 지속적인 $\mathrm{IMC}$ 전략을 개발/실행함으로써 소비자들의 마음속 에 시장 1 위의 대표 카드브랜드라는 이미지를 심는데 성공했다. 2007년 LG카드와 합병한 신 한카드가 강력하고 차별적인 브랜드이미지를 구 축하기 위해 도입된 $\mathrm{IMC}$ 전략을 광고 캠페인과 기타 마케팅 커뮤니케이션활동으로 나누어 살 펴보기로 한다.

\section{1 광고 캠페인}

\subsection{1 브랜드 인지도 구축(1차 광고캠페인)}

2007년 신한카드는 LG카드와의 통합을 통해 규모면에서 단연 국내에서 가장 큰 카드사가 되었지만 여전히 소비자는 신한카드를 후발 카
드 브랜드로 인식하고 있었다.

이러한 시장상황 속에서 신한카드가 카드시장 에서 대표브랜드임을 알리기 위한 마케팅커뮤 니케이션이 필요함을 인식했다. 이에 따라 소비 자에게 LG카드와의 합병을 알리고 한국 대표 신용카드브랜드임을 소비자 마음속에 구축하기 위한 1 차 광고캠페인을 도입했고 광고모델로는 이영애씨를 선정했다.

일반적으로 소비자들은 전문지식(expertise)을 갖추고 있는 것으로 생각되거나, 호감(likability) 을 주며, 친숙함이 느껴지는 광고모델에 대해 신뢰성이 높다고 지각한다. 따라서 한국의 대표 적 배우인 이영애를 광고모델로 사용한 것은 1 등 카드브랜드라는 연상을 소비자 마음속에 형 성하는 데 도움이 될 것으로 판단했다. 1 차 광 고캠페인은 최고의 여배우이면서 과거 LG카드 의 모델이었던 이영애를 통해 LG카드와의 합 병을 알림과 동시에 '신한카드가 카드의 답을 말한다'라는 메시지와 'The Answer'라는 슬로 건을 통해 신한카드가 한국 최고의 금융브랜드

〈그림 2-1〉 브랜드 인지도 구축 광고캠페인
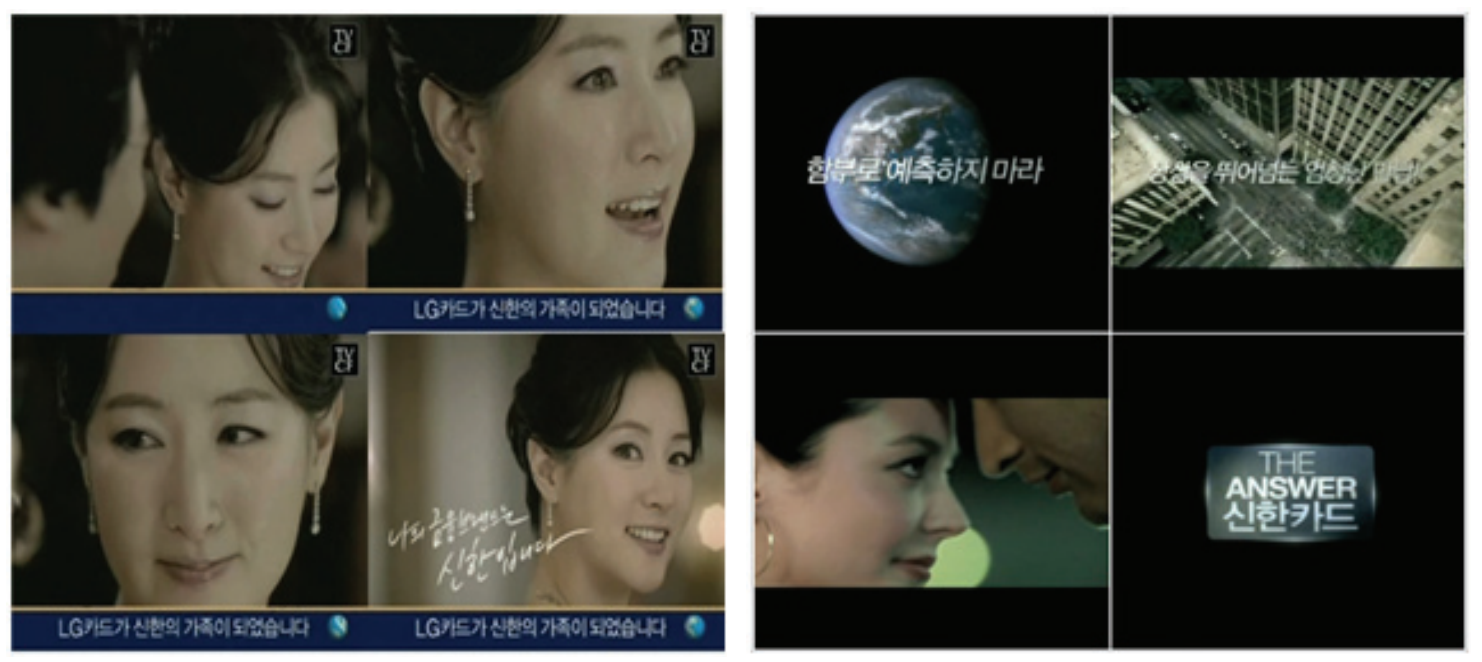

신한카드 브랜드구축을 위한 IMC전략 251 
를 지향함을 전달하였다. 또한 크리에이티브 측 면에서 국내 최초로 영화 예고편 형식을 선택 하였고 신한카드와 LG카드의 만남을 블록버스 터 편과 로맨틱코미디 편으로 재구성하여 소비 자들로 하여금 광고에 대한 주목도를 높이고 차기 광고에 대한 기대감을 극대화시켰다.

1차 광고캠페인은 '2007 아시아경제 광고 대 상'에서 카드 부문상을 수상하였고, 론칭 40일 만에 신한카드와 LG카드의 통합 인지율을 $93.3 \%$ 로 끌어 올리고, 카드사 브랜드 인지도 $89 \%$ 를 달성함으로써 높은 브랜드인지도 구축이라는 광고목표를 달성하는데 성공했다.

\subsection{2 차별적 브랜드이미지 구축 (2차 광고캠페인)}

2008년 들어 신한카드는 LG카드와의 통합으 로 인해 발생될 기존고객 이탈을 방지하기 위 해 어떻게 해야 할 것인지에 대해 고민을 하게 된다. 다양한 카드를 소지한 고객들에게 경쟁카 드에 비해 차별적인 혜텍과 고객서비스를 개발
하고 마케팅커뮤니케이션을 통해 이를 전달함 으로써 소비자의 마음속에 제품속성상에서의 차별적 연상을 구축하는 것이 핵심과제였다.

경쟁이 날로 치열해 지는 카드시장에서 기존 고객의 사용률을 유지/강화하고 신규고객을 끌 어 들이기 위해 카드의 혜택 및 서비스 측면에 서 경쟁사와의 차별화가 필요한 상황이었다. 또 한 전업카드(삼성카드, $\mathrm{BC}$ 카드, 현대카드)에 비 해 은행카드(신한카드, 국민카드, 우리카드)의 혜택 및 서비스가 약하다는 부정적인 연상도 제거해야 했다.

이에 따라 2008년 신한카드는 '고객 니즈에 부합하는 새로운 서비스와 혜택을 경쟁사보다 앞서서 제공하는 카드사'라는 차별적 브랜드이 미지를 소비자 마음속에 구축하기 위해 2차 광 고캠페인을 도입했다. 소비자들은 당시 여러 장 의 카드로 다양한 니즈를 충족시키고 있었다. 신한카드는 소비자의 다양한 라이프스타일을 모두 커버할 수 있는 “최적의 카드서비스 콤비 네이션'이라는 차별적 제품편익을 개발하고 광 고캠페인을 통해 이를 부각시키고자 했다.

〈그림 2-2〉 브랜드 이미지 차별화를 위한 콤비네이션 카드 광고
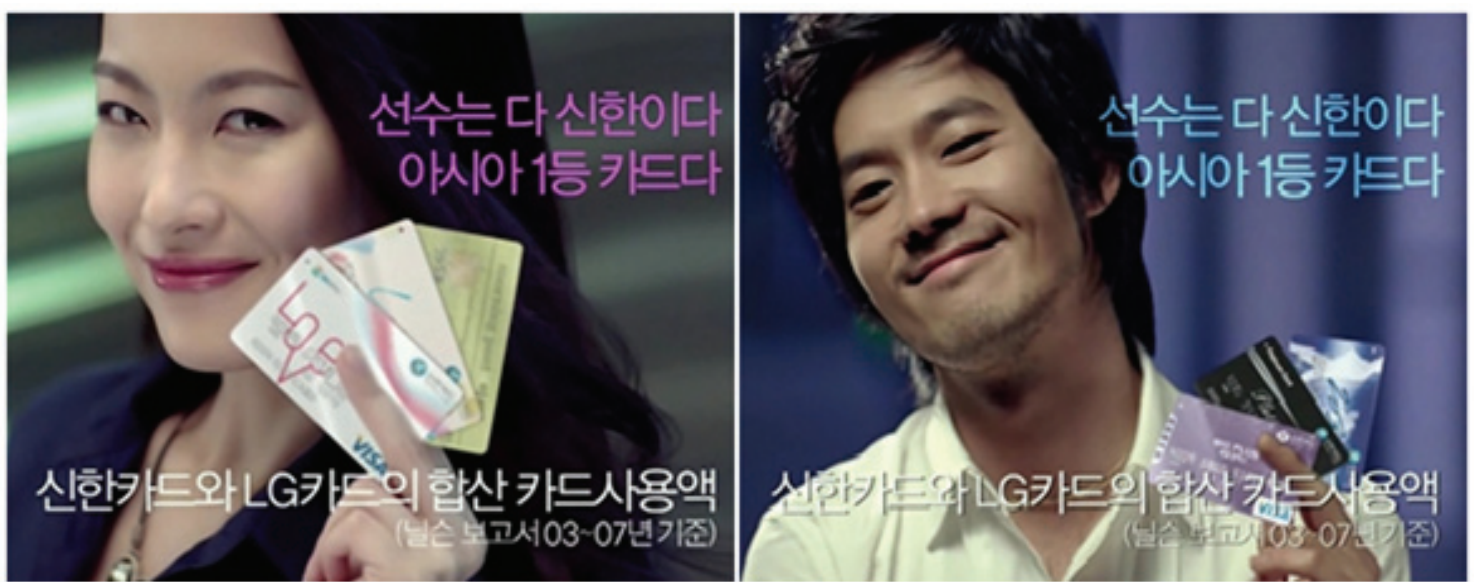
‘최적의 카드 콤비네이션' 이라는 제품개념과 광고주제는 '신한카드'만으로 최적의 카드서비 스 콤비네이션을 구성하는 방법을 알려 주고 소비자 스스로 자신의 라이프스타일에 맞는 최 적의 카드 콤비네이션을 구성하도록 유도함으 로써 이미 대한민국 1300 만 명의 고객지갑 속 에 침투해 있는 신한카드에 대한 충성도를 구 축하고 사용률을 제고하는데 그 목적이 있다.

2차 광고캠페인에서 신한카드는 '최적의 카드 콤비네이션' 라는 광고주제를 상징적으로 표현 하기 위해 '선수'라는 단어를 사용했다. 여기서 '선수란 히든 카드, 반전의 카드, 최선의 카드 등 '카드'를 잘 꺼내 쓰는 사람과 같이 일상생 활에서 상황에 맞게 써야 할 카드를 정확히 알 고 있고, 카드를 사용하면서 최대한의 혜택을 누리는 카드사용의 달인이라는 의미와 신한카 드가 여러 카드들 가운데 선수라는 의미를 중 의적으로 표현하는 것이다. '선수는 다 신한이 다!'라는 핵심 메시지를 통해 전문적이고 앞서 가는 카드브랜드이며 신한카드만으로 최적의 서비스 콤비네이션을 구성할 수 있다는 차별적 브랜드이미지를 구축하였다.

2차 캠페인은 신한카드의 대표카드 6종을 소 재로 총 2편의 TV광고물을 제작하였다. '선수 남' 편과 '선수녀' 편으로 구성된 '선수' 광고캠 페인은 각 '선수'들이 자신의 라이프스타일에 맞추어 카드혜택을 즐기는 내용을 유쾌한 톤으 로 담고 있으며, 선수남 편(신한플래티늄, 신한 2030, 신한빅플러스)과 선수녀 편(신한레이디, 신한LOVE, 신한아침愛)에서 각각 세 개의 카 드를 선보였다. 특정 브랜드와 관련된 연상들은 소비자의 기억 속에 그물처럼 연결되어 있어, 하나의 연상이 활성화(activation)되면(떠오르
면) 그와 연결된 다른 연상들이 연속적으로 떠 오른다(Collins and Loftus, 1975). 신한카드는 선수라는 단어를 자사의 3 개의 카드와 연결시 켜 소비자가 다양한 구매상황에서 신한카드만 을 떠올리도록 만들었다. 이러한 마케팅커뮤니 케이션 활동을 통해 신한LOVE카드는 영업 개 시 후 5 개월 만에 발급 계좌 수가 100 만 계좌 를 돌파했고 한 회사의 여러 장의 카드를 조합 하는 차별화된 서비스제공물을 통해 신한카드 를 차별화시키는데 성공했다.

\subsection{3 고객관계 구축(3차 광고캠페인)}

2009년 들어 카드업계 1위의 자리를 구축한 신한카드는 " 1 등 기업으로서 고객을 위해 무엇 을 해야 할까라는 고민을 하게 되었다. 신한카 드는 1 등 카드사로서 어떻게 하면 고객을 더 기쁘게 할 수 있을까, 즉 브랜드-고객 과의 유 대감 형성을 통해 구축된 브랜드파워를 더욱 강화시키고자 했다. 이에 따라 신한카드는 항상 고객을 위한 카드만 생각한다는 의미인 '생각하 는 카드'를 광고테마로 한 3 차 광고캠페인을 기 획했다. 런칭 광고물은 두 편으로서, 신한카드의 1400 만 고객을 항상 생각한다는 내용의 ' 1400 만 고객 사랑' 편과 받은 사랑을 돌려드리기 위해 끝없이 고객만족을 실천한다는 내용의 '끝없는 고객만족' 편이었다.

일반적으로 소비자가 제품정보에 대해 적극적 으로(actively), 그리고 깊이 있게(deeply) 생각 할수록 보다 강력한 브랜드연상이 기억 속에 형성되며 필요할 때마다 쉽게 기억으로부터 인 출된다(Craik and Lockhart, 1972). 3차 캠페인 은 1 등 카드인 신한카드가 고객을 위한 카드의 
〈그림 2-3〉 고객관계구축 광고

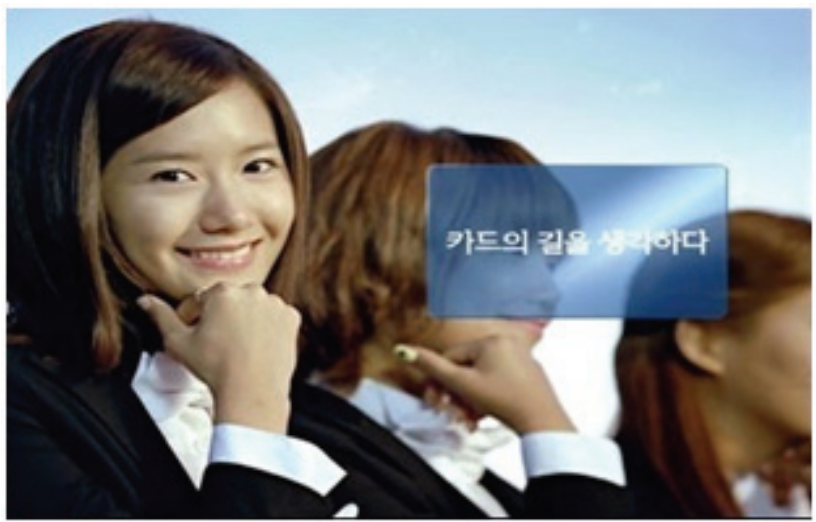

새로운 길을 개척해나간다는 메시지를 고객님 때문이라는 친숙하면서도 중독성 있는 징글을 통해 자만하지 않고 겸손한 자세로 고객을 대 하겠다는 신한카드의 의지를 효과적으로 전달 했다.

또한 신한카드의 “고객님 덕분입니다” 캠페인 은 고객만족을 향한 신한카드의 전사적 노력과 자만하지 않고 겸손하겠다는 자세를 전달함으 로써 고객들의 기억에 신한카드에 대한 긍정적
태도와 감정이 형성되도록 하였다. 덕분 이라는 말은 좋은 일이 생겼을 때 스스로의 능력으로 이루었다고 자만하지 않고 '주위의 도움과 격려 덕분'이라고 감사를 돌린다는 것을 의미한다.

“덕분”을 키워드로 하는 일련의 광고물들은 다양한 고객의 일상생활 속에서 신한카드와 고 객들간의 공감대 형성을 통해 행복 바이러스가 퍼져감을 보여줌으로써 브랜드와의 정서적 유 대감을 형성하는데 기여했다.

〈그림 2-4〉 고객에게 감사함을 전달하는 광고
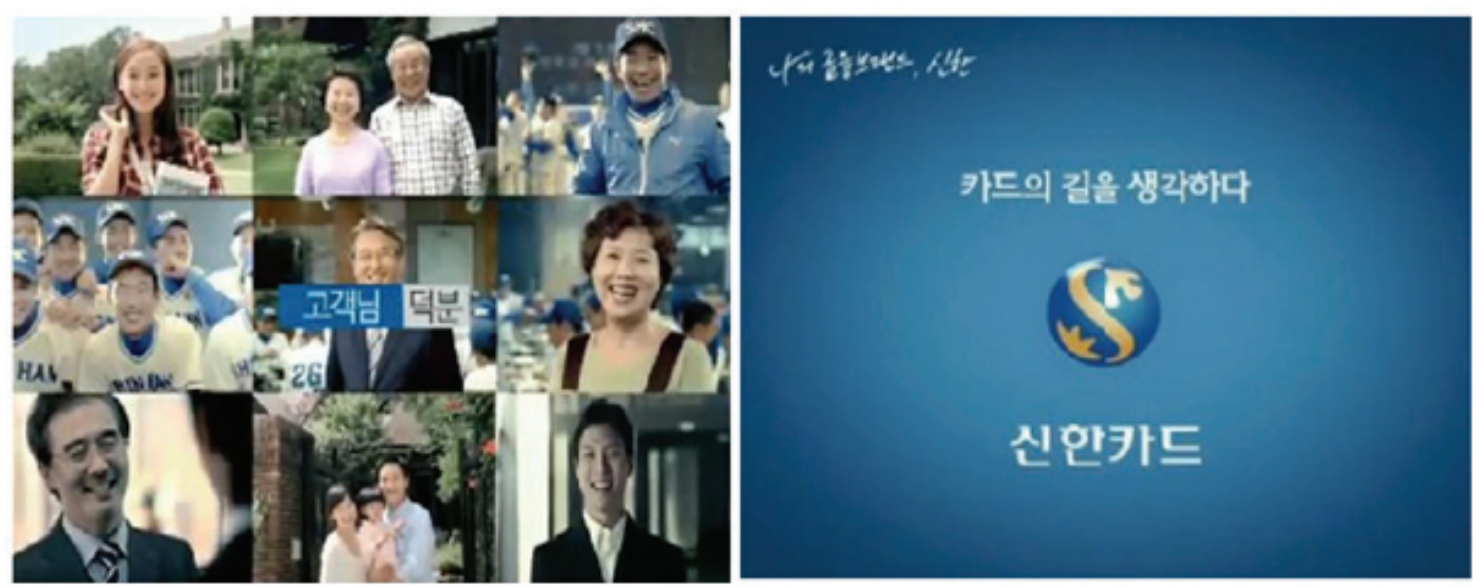


\subsection{4 고객관계 강화 (4차 광고캠페인)}

2010년 신한카드는 고객과의 관계를 더욱 강 화시키기 위해 ‘좋아요!'를 키워드로 한 4차 캠 페인을 전개했는데, 말하는 사람도 좋고 듣는 사람도 기분이 좋아지는 마력의 단어 '좋아요!' 를 통해 모든 국민들에게 사회 통합과 상생의 메시지를 전파하려고 했다.

'카드의 길을 생각하다' 3 차 캠페인을 런칭 한 이후, '생각-최초-덕분'으로 이어지는 신한카드 의 'Song' 캠페인으로 고객의 눈과 귀를 사로잡 은 신한카드는 좋아요 광고캠페인을 통해 고객 들이 '선호하는' 브랜드에서 '사랑하는' 브랜드 로 전환시키고자 했다.

4차 캠페인의 주제는 '모두를 위한 카드’로 정 했다. 이 캠페인은 연령과 성별의 차이를 뛰어 넘고 심지어는 신한카드를 가지고 있지 않은 고객까지도 기쁘게 하는 카드로 포지셔닝함으 로써 고객과의 관계를 더욱 강화시키는데 목표 를 두었다.

4차 캠페인에서는 “이런 신한카드”라는 카피
에 “좋아요!”라는 목소리와 함께 ‘좋아요' 아이 콘이 뜨고, 주유, 전철, 버스, 택시와 같은 대중 교통수단을 모두 할인해주는 신한카드(신한GS 칼텍스Shine카드, 신한SK에너지OILing카드)에 대해 수많은 사람들이 “좋아요”를 외치는 장면 을 보여준다. 바로 이어 카페, 레스토랑, 패션 등 자신이 직접 지정한 단골길(전국 30 여개 거 리)에 있는 가게에서 모두 적립이 되는 신한카드 (신한 하이포인트카드 나노F)가 소개되고, 이 카드를 좋아하는 여러 사람들이 또 “좋아요”를 외친다.

4 차 캠페인은 보다 젊고 밝은 표정의 젊은 고 객들을 등장시킴으로써 브랜드연상을 더욱 풍 부하게 하고 신한카드를 사용하는 모든 사람들 이 신한카드를 진정한 카드로 여긴고 좋아함을 보여줌으로써 고객의 브랜드애착을 구축하는데 도움을 주었다.

\section{2 기타 마케팅 커뮤니케이션 전략}

신한카드는 2007년 출범 이후 브랜드 인지도

〈그림 2-5〉 고객관계강화 광고

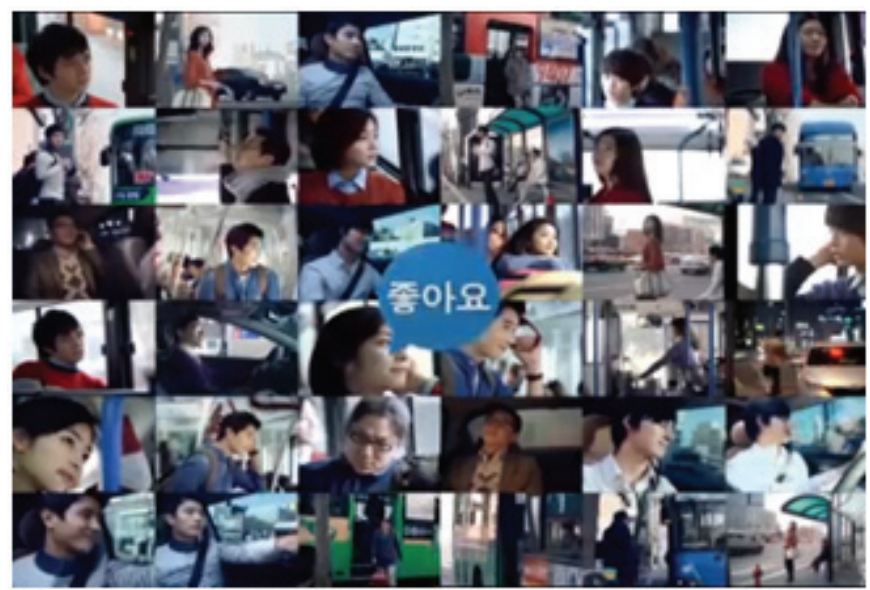


제고와 차별적 이미지구축을 위해 매체 광고외 에도 문화/스포츠 마케팅, 공간마케팅(브랜드 존)와 같은 이벤트마케팅, 그리고 사화공헌과 같은 홍보활동을 통합적으로 수행해 왔다.

\subsection{1 문화/스포츠 마케팅}

신한카드는 LOVE Concert, LOVE Classic, LOVE Day, LOVE Culture로 구성된 LOVE '시리즈'를 운영했다. 광주, 대전, 대구, 부산 등 지방을 돌며 고객 초청 투어 콘서트를 개최하 고, VIP 고객을 초청하여 클래식 공연을 관람 하게 하고, 프로스포츠 인기경기에 고객을 초청 하는 등 다양한 문화 컨텐츠를 “LOVE”를 키 워드로 하여 시리즈화하는 문화 마케팅을 전개 하였다. 이렇게 대중공연, 클래식, 미술/사진, 스포츠, 뮤지컬, 오페라, 전시회 등 다양한 분야 에 대한 스폰서십을 통해 문화예술 지원 활동 을 전개하고 동시에 당사 고객에게 문화적 혜 택을 제공하는 문화활동을 진행함으로써 "고객 님 덕분"이라는 키워드를 고객서비스를 통해 실천하고 고객의 브랜드충성도를 강화시켰다

\subsection{2 공간 마케팅}

신한카드는 〈브랜드 Zone〉 개발을 통해 공간 마케팅을 추진하였다. 대표적으로 남산 $\mathrm{N}$ 서울 타워, 타임스퀘어 아트홀, 명동 예술극장을 대 상으로 공간마케팅을 추진하였으며 이를 통해 고객들의 신한카드 혜택 체험이 가능하도록 하 였다.

남산 $\mathrm{N}$ 서울타워에서 진행하는 행사는 남산의 친환경 이미지를 신한카드에 연계하여 방문 시
민에게 신한카드의 브랜드 이미지를 제고하는 데 초점을 두고 있는데, 년간 방문객이 500만명 인 서울타워의 메인 벽면에 광고/홍보물을 게 재하여 신한카드의 브랜드를 알리고 타워 내 주요 가맹점 상시 할인율 제공, 시즌별 스페셜 프로모션 실시, 친환경 캠페인 'Green N Market' 등의 이벤트를 실시하여 고객들의 체험을 이끌 어 내고 있다.

\subsection{3 사회공헌 마케팅}

신한카드는 사회공헌활동을 통한 브랜드진정 성의 제고를 통해 브랜드 파워를 강화하고 있 다. 기업의 사회공헌 활동은 기업에 대한 소비 자 태도, 그리고 판매되는 제품브랜드에 대한 태도 및 구매의도 등에 긍정적인 영향을 준다. 신한카드는 여러가지 사회공헌 프로그램을 운 영하고 있는데, 그 대표적인 활동이 기부전용 사이트인 '아름인'의 운영이다.

아름인은 편리한 기부문화의 제공을 통해서 사회소외계층에 대한 후원을 도모하는 캠페인 이다. 주요 복지단체 400여개를 기부처로 등록 하고 다양한 분야의 테마를 중심으로 한 기부 캠페인을 진행하면서 긴급 이슈에 대한 단발성 기부 캠페인인 이슈기부 행사도 진행하고 있다. 업계 최초 포인트 기부 전용 신용카드인 '아름 다운 카드'의 운영을 통해 편리한 기부문화를 제공함과 동시에 사회 소외계층 후원을 도모한 다. 아름다운 카드의 현재 회원수는 40 만명으로 기업과 소비자가 함께 벌이는 기부행사라는점 에서 긍정적으로 평가된다.

그리고 소외계층 아동과 청소년에게 친환경 독서 환경을 제공하기 위하여 '아름인 도서관' 
지원사업도 실시하고 있는데, 전국 230여개 지 역아동센터를 대상으로 친환경 도서관 구축, 아 동. 청소년 권장도서 센터별 1 천여권 지원, 임 직원이 같이 참여하는 임직원 도서기증 캠페인, 청소년 금융교육 등의 사업을 전개하고 있다.

앞서 언급한 LOVE Concert, LOVE Day , Sponsorship, 브랜드존과 같은 홍보활동과 사회 공헌 마케팅은 브랜드 노출 강화, 고객 참여 확 대를 통해 신한카드의 긍정적 이미지를 강화하 는데 공헌한다.

\section{III. 고객자산 구축을 위한 내/외부 고객 마케팅}

신한카드는 타 카드사와 차별화된 CS전략을 내세웠다. 신한카드의 CS 목표는 차별적인 고 객경험 관리를 통해 1 등 카드사의 위치를 유지 하는 것인데, 이러한 목표를 실현하기 위한 신
한카드의 노력은 외부고객 만족을 위한 마케팅 활동과 내부고객 만족을 위한 마케팅 활동으로 나누어진다.

\section{1 외부고객 만족을 위한 마케팅}

신한카드의 외부고객 만족전략은 고객의 소리 리뷰, 고객패널 운영, IMC 협의체, 6 시그마 도 입 등으로 구성된다.

먼저, 신한카드는 고객의 소리를 사장까지도 들을 수 있는 시스템을 구축했다. 즉 상담원의 통화내용은 바로바로 전산에 등록하도록 돼 있 는데, CS팀에서는 고객의 소리를 매일 리뷰하 여 그 내용을 CS 개선과제로 이슈화한다. 개선 과제는 내용에 따라 즉시 개선할 수 있는 것과 정책적 개선이 필요한 과제로 분류해 개선활동 을 전개한다. 이 회의에는 임원진도 함께 참여 해 실질적인 개선이 될 수 있도록 힘을 쏟고 있다.

또한 신한카드는 고객패널제도를 운영하는데,

\section{〈그림 3-1〉 외부고객 만족 전략}

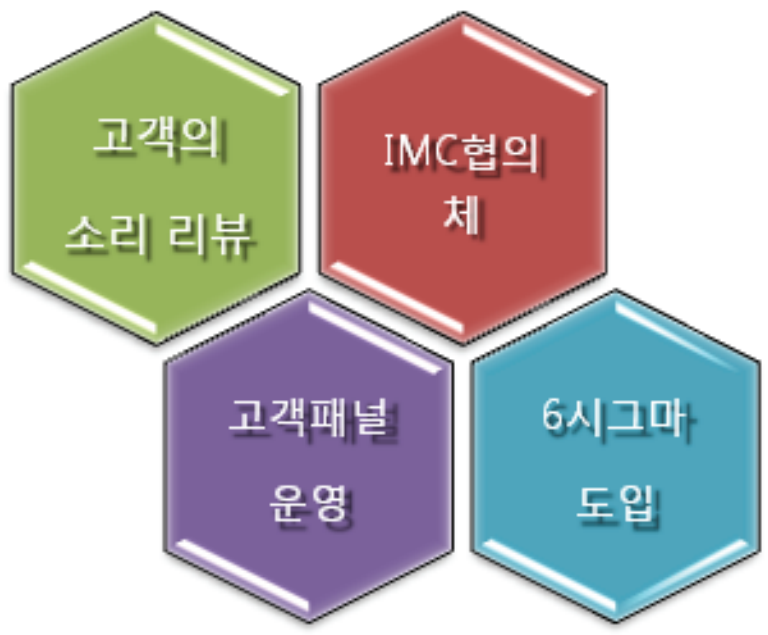


고객패널제도는 MOT(Moment of Truth)서비 스 경험 후 서비스 품질에 대한 평가를 통해 마케팅 활성화를 위한 아이디어 제안, 신상품 서비스 개발 등 에 활용하는 것이다. 고객패널 은 $\mathrm{MOT}$ 개선 작업 시 고객을 직접 참여시킴 으로써 고객의 의견을 사전에 반영하기 때문에 고객의 니즈를 충분히 반영하는 신제품을 개발 하는데 유용하게 활용된다. 고객패널제도는 고 객이 원하는 카드의 혜택을 선택할 수 있는 '하 이포인트카드 nano'와 신용카드 포인트를 현금 처럼 활용하여 은행 예·적금이나 증권사 펀드 에 납입할 수 있는 금융 복합 상품인 'S-more 카드'를 출시하는데 도움을 주었다.

$\mathrm{IMC}$ 협의체에서는 어떻게 하면 고객들에게 일 관성 있게 브랜드를 어필할 수 있을지를 연구 한다. $\mathrm{IMC}$ 협의체는 다양한 마케팅커뮤니케이션 전략들이 시너지 효과를 낼수있도록 이들을 조 정/통합한 역할을 수행한다.

신한카드는 지속가능한 성장을 달성하기 위해 새로운 조직문화 및 혁신 엔진으로서 6시그마
를 전사적으로 도입하게 되었다. 신한카드는 2006 년 4 월20일부터 6 시그마 운동의 일원으로 업무 혁신 S\&S(slim and simple) 운동을 전개하기 시 작했는데, 고객에게 더 편리한 상품이나 서비 스, 경험을 제공하면서 비용을 절감하는데 그 목적이 있다. 이러한 6시그마의 도입은 그 동안 정성적으로만 이루어졌던 고객만족이라는 개념 을 정량적으로 접근하는 계기를 마련하였다.

이러한 신한카드의 외부고객에 대한 마케팅 노력의 결과 2010년 한국 표준협회, 한국 능률 협회, 한국 생산성본부 등 공인된 3 개 기관에서 조사한 고객 만족도에서 평균 2 위를 차지했다.

\section{2 내부고객만족을 위한 마케팅}

신한카드는 직원이 즐거워야 고객도 즐겁다는 원칙을 갖고 내부고객을 위한 다양한 프로그램 을 진행하고 있다. 그 대표적인 프로그램이 직 원들의 애로사항을 적극적으로 해결해주는 직 원지원프로그램(EAP)이다. 또한 매월 다양한

〈그림 3-2〉 고객만족도 조사 결과

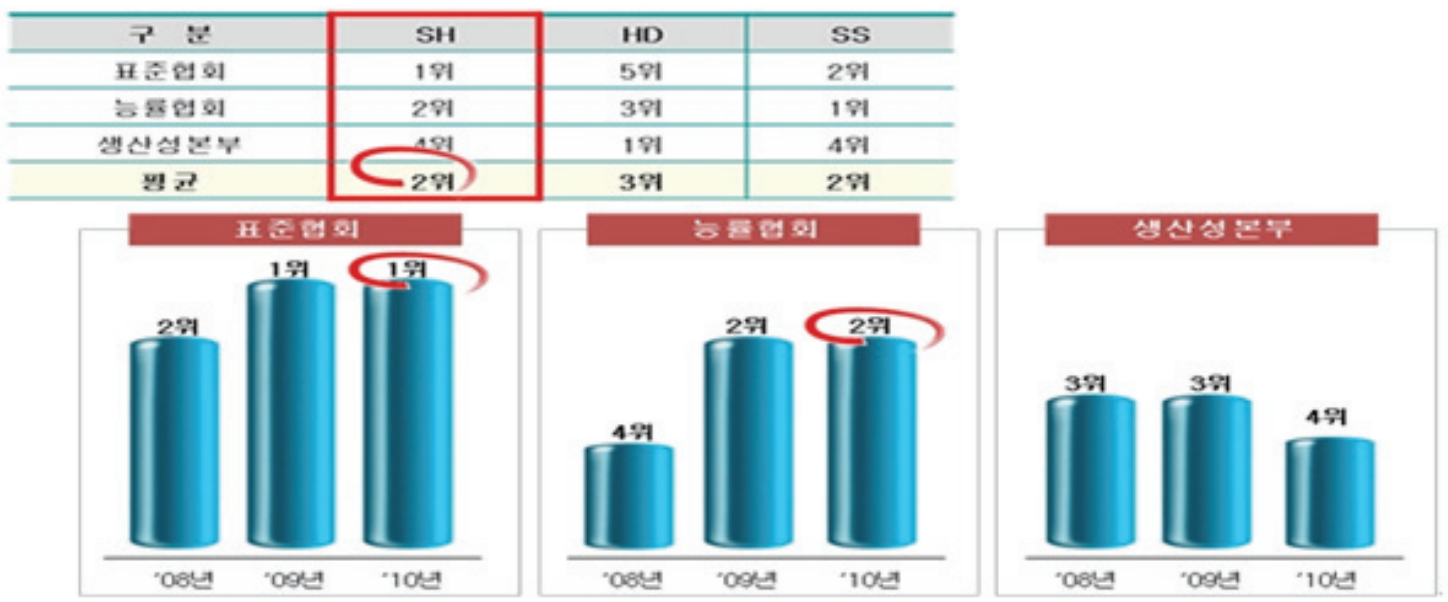


가족참여 프로그램을 제공하여 가족과 하나되 는 회사를 만들어 나가고 있다. 직원들의 고양 과 전문지식의 함양을 위하여 최신 경영/인문 관련서적과 영상물을 제공하는 정보 자료실 운 영하고 있다. 더나아가 직원들의 니즈를 반영하 여 구매 신청이 있는 서적을 매월 40 50권, 영 상물 10 20편씩 추가 구매하고 있다.

신한카드는 직원들의 근로의욕 고취를 위해 다양한 복지혜택을 제공하고 있는데, 일괄적인 복지가 아닌 맞춤형 복지혜택을 제공하기 위하 여 여러가지 선택항목을 정하여 본인의 포인트 한도 내에서 상시 활용할 수 있도록 하는 카페 테리아식 복지제도를 운영하고 있다. 업무관련 자기개발을 위한 어학, 컴퓨터, 운전면허 등의 이용 및 도서구입, 건강증진과 건전한 레저활동 및 심신개발 항목, 유아 및 자녀 양육을 위한 교육기관 이용(유치원, 탁아비 외), 휴양시설 (콘도/리조트) 및 놀이공원 이용, 스킨스쿠버, 행글라이딩, 문화생활(연극, 연화, 전시회, 각종
콘서트, 음반/DVD 구입, 스포츠 관람 등). 여 행서비스 및 자동차 보험가입 지원 등 카페에 서 자신이 좋아하는 식음료를 선택하듯 자신의 취미와 필요에 맞추어 복지혜택을 누릴 수 있 게 해 줌으로써 내부고객인 직원들의 만족도를 극대화 시키고 있다.

\section{IV. 마케팅 성과}

신한카드의 지속적인 IMC전략의 개발과 실행 을 통한 브랜드구축은 높은 마케팅성과를 통해 나타나고 있다. 먼저 개인 신용판매 취급액에서 신한카드가 독보적인 1 위 지위를 유지하고 있 는데, 1 위인 신한카드가 69.6 조원으로 2 위인 $\mathrm{H}$ 사(44.6조원)과 무려 25조원이 차이가 나고 있다.

카드업계의 시장 점유율은 신한 카드가 3 년 평균 $24.1 \%$ 로 1 위의 시장지위를 차지하고 있으

〈그림 4-1〉개인 신용판매 취급액

(단위 : 조원, \%)

\begin{tabular}{|c|c|c|c|c|c|c|c|}
\hline & \multicolumn{2}{|c|}{$\underline{1 Q}$} & $\underline{2 Q}$ & $\underline{3 Q}$ & $\underline{4 Q}$ & 눈년 & $\frac{\text { 저ㄴㅕㅕ }}{\text { 매비 }}$ \\
\hline - SHC & 16 & & 17.1 & 17.7 & 18.8 & 69.6 & $(+11,4)$ \\
\hline - K訲 & 8.7 & 9.2 & 9.7 & 10.2 & & 37.9 & $(+3,4)$ \\
\hline - S圾 & 8.7 & 8.7 & 9.3 & 9.7 & & 36.3 & $(+3.7)$ \\
\hline - $\mathrm{H} \overline{\text { àt }}$ & 10.3 & 10.6 & 11.5 & 12.2 & & 44.6 & $(+5.6)$ \\
\hline
\end{tabular}




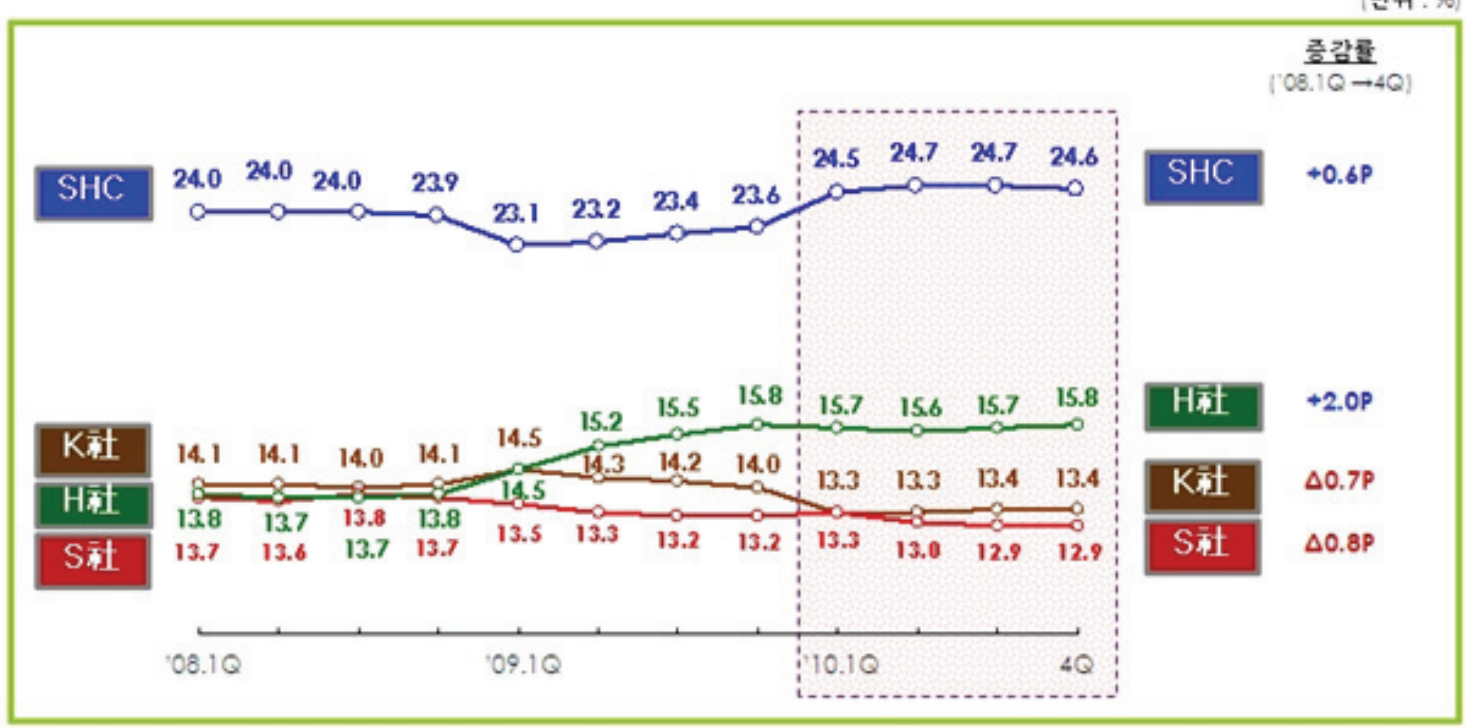

며, 기타 3 사가 2 위를 차지하기 위해 경쟁하고 있다.

2007년, LG카드의 만남을 영화 예고편 형식 을 이용해 전개한 1 차 광고캠페인을 론칭한지 40 일만에 신한카드와 LG카드의 통합 인지율이 $93.3 \%$ 에 이르렀으며, 카드사 인지도 $89 \%$ 를 통 해 1 등 카드브랜드로서의 위상을 구축했다. 그 이후 지금까지 지속적인 통합적 마케팅커뮤니 케이션을 통해 구축된 높은 브랜드 인지도와 강력하고 차별적인 브랜드이미지를 기반으로 신한카드는 현재 취급액 100 조원, 순이익 1 조 4876 억 원, 시장점유율 약 $25 \%$ 로 순항을 계속 하고 있다.

신한카드는 2009년 지속적인 CS경영활동으로 2009년 '한국에서 가장 존경받는 기업' 신용카 드 부문에 2년 연속 1 위에 선정된 데 이어 '고 객만족경영대상'을 2년 연속 수상하는 영예를 안았다. 또 한국 소비자포럼 주관 '올해의 브랜
드 대상 수상 및 2009년 신용카드 부문에서 브 랜드스톡 1 위에 선정되기도 하였으며, 2009년 대한민국 서비스 사업 전반에 대한 품질수준을 측정, 평가하는 제도인 '한국서비스품질지수 조 사'에서 신용카드 부문 1 위 기업으로 선정되었 다. 뿐만 아니라 '소비자 신뢰 대표 브랜드 대 상', '고객만족경영대상' 3년 연속 수상 등 서비 스 품질과 소비자 만족 측면에서 많은 성과를 보여 왔다. 2010년, 대한민국 대표 브랜드로 선 정되어 대상을 수상했으며, 한국에서 가장 존경 받는 기업으로 3 년 연속 1 위로 선정되기도 했다.

신한카드는 지속적이고 효율적인 브랜드 관리 를 위해 2008년부터 내부 BPI(Brand Power Index)모델을 개발하여 정기적인 Tracking을 바탕으로 지속적으로 브랜드 요소를 관리하였 다. 2009년 상반기 3위에 머물렀던 신한카드는 2011년 상반기에는 1위를 차지하는 등 신한카 드 $\mathrm{BPI}$ 는 매년 지속적인 상승세를 보였다. 
2010

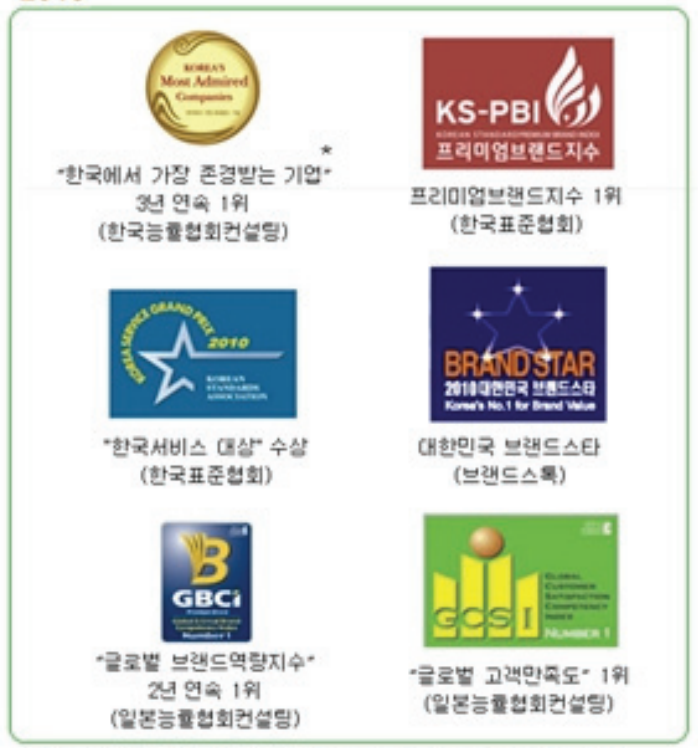

- 한국예서 가장 존경발는 기연은 4년 연속 1위: 2011년도 수상

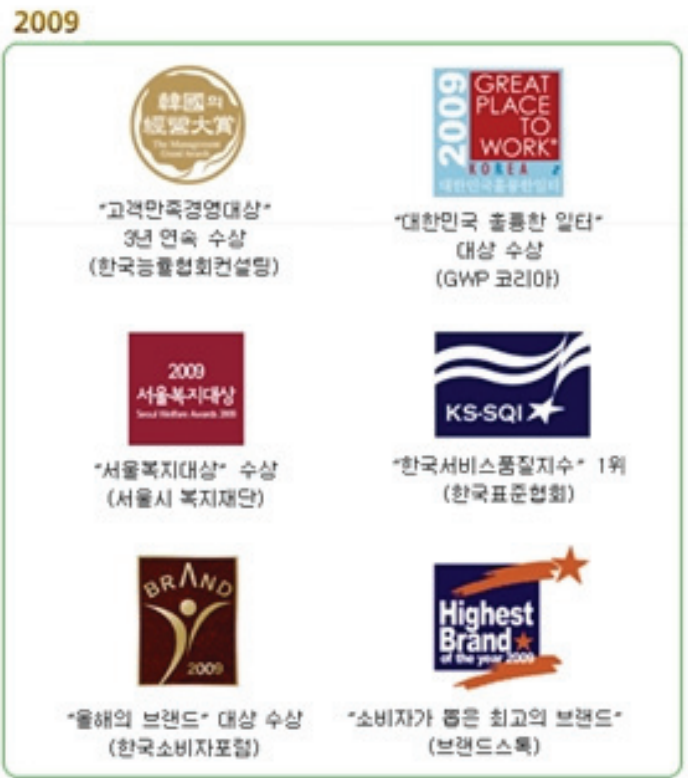

〈그림 4-4〉 BPI 모델

[ 신한카드 내부 BPI Moedl ]

* 주관 : 한국 생산성본부 서울마케팅리서치 등

× 조사 시기: 연간 2회(상/하반기 1회씩)

* 조사 설계

\begin{tabular}{|l|l|}
\hline 목적 & - 브랜드 Power Index Tracking \\
\hline 방법 & - 1 대1 개별 면접 \\
\hline 대상 & - 신한, $\mathrm{BC}$, 상성, $\mathrm{KB}$, 현대, 롯데 \\
\hline 표본 & $\begin{array}{l}\text { - 20 59세 성인 남녀 } 1,000 \text { 명 } \\
\text { - 수도권 및 전국 } 5 \text { 대 광역시 }\end{array}$ \\
\hline
\end{tabular}

$*$ 조사 모델

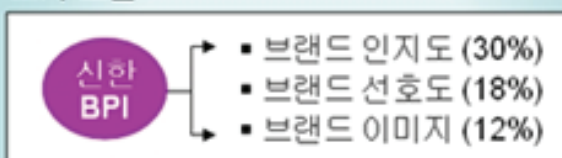

[ BPI Tracking 】

\begin{tabular}{|c|c|c|c|c|c|}
\hline 구분 & $\begin{array}{c}\text { 09년 } \\
\text { 상반기 }\end{array}$ & $\begin{array}{c}\text { 09년 } \\
\text { 하반기 }\end{array}$ & $\begin{array}{c}10 \text { 년 } \\
\text { 상반기 }\end{array}$ & $\begin{array}{c}10 \text { 년 } \\
\text { 하반기 }\end{array}$ & $\begin{array}{c}11 \text { 년 } \\
\text { 상반기 }\end{array}$ \\
\hline 신한 & $\begin{array}{l}49.8 \\
\text { (3위) }\end{array}$ & $\begin{array}{l}51.3 \\
\text { (2위) }\end{array}$ & $\begin{array}{l}52.9 \\
\text { (2위) }\end{array}$ & $\begin{array}{c}55.9 \\
\text { (2웨) }\end{array}$ & $\begin{array}{r}\sqrt{56.4}_{56} \\
\text { (1위) }\end{array}$ \\
\hline BC & $\begin{array}{l}53.3 \\
\text { (1위) }\end{array}$ & $\begin{array}{l}58.8 \\
\text { (1위) }\end{array}$ & $\begin{array}{l}58.3 \\
\text { (1위) }\end{array}$ & $\begin{array}{l}58.5 \\
\text { (1위) }\end{array}$ & $\begin{array}{l}56.0 \\
(2 \text { 위) }\end{array}$ \\
\hline 삼성 & $\begin{array}{l}50.8 \\
(2 \text { 위 })\end{array}$ & $\begin{array}{l}50.5 \\
\text { (3위) }\end{array}$ & $\begin{array}{l}48.1 \\
\text { (3위) }\end{array}$ & $\begin{array}{l}51.4 \\
\text { (4위) }\end{array}$ & $\begin{array}{l}51.5 \\
\text { (3위) }\end{array}$ \\
\hline 현대 & $\begin{array}{c}41.3 \\
\text { (5위) }\end{array}$ & $\begin{array}{l}47.9 \\
(4 \text { 위) }\end{array}$ & $\begin{array}{l}45.9 \\
(5 \text { 위) }\end{array}$ & $\begin{array}{l}49.7 \\
(5 \text { 위) }\end{array}$ & $\begin{array}{l}50.4 \\
(4 \text { 위) }\end{array}$ \\
\hline KB & $\begin{array}{l}49.1 \\
(4 \text { 위 })\end{array}$ & $\begin{array}{l}47.7 \\
\text { (5위) }\end{array}$ & $\begin{array}{l}47.2 \\
(4 \text { 위) }\end{array}$ & $\begin{array}{l}51.7 \\
\text { (3위) }\end{array}$ & $\begin{array}{l}49.3 \\
(5 \text { 위) }\end{array}$ \\
\hline 롯데 & - & - & - & $\begin{array}{l}43.2 \\
\text { (6위) }\end{array}$ & $\begin{array}{l}43.0 \\
\text { (6위) }\end{array}$ \\
\hline
\end{tabular}




\section{V. 결 론}

신한카드는 고객 입장에서 모든 경영활동을 재정립하고, 그룹 핵심가치인 '고객중심'의 경영 을 실천하기 위하여 노력해 왔다. 신한카드의 목표는 모든 것을 고객 입장에서 생각하고, 판 단하고, 행동하는 고객만족경영을 실천하는 것 으로, 모든 생활금융서비스를 카드 한 장으로 누릴 수 있는 시대, 즉 'All in One' 시대를 선 도하고, 고객 한 사람 한 사람을 위해 모든 정 성을 다한다는 'All for one' 정신으로 다가가는 카드를 표방하는 것이다

신한카드는 철저하게 계획된 IMC전략의 실행 을 통해 높은 브랜드 인지도, 차별적 브랜드 이 미지 형성, 매출액 증가 등 많은 긍정적 성과를 이루었으나 1 등 카드로서의 위상을 지켜나가고 브랜드충성도를 더욱더 강화시키기 위해 앞으 로 해야 할 일들이 더 많을 것이다.

첫번째는 $\mathrm{TV}$ 뱅킹 서비스를 제공하는 것이 다. 텔레뱅킹과 인터넷뱅킹에 이어 이른바 'TV 뱅킹' 시대가 시자도미에 따라 신한카드는 쌍방 향 IP 미디어를 통해 각종 은행업무를 처리할 수 있는 인터넷TV 뱅킹 서비스를 선보이려 한 다. TV용 리모컨으로 계좌 조회와 이체, 공과 금 납부 등을 처리할 수 있으며, 인터넷 뱅킹을 이용할 수도 있다.

두번째는 기여도에 따른 부가적 서비스을 제 공하는 것이다. 신한카드는 고객 기여도에 따라 차별화 된 금융서비스를 제공하려고 한다. 기여 도가 높은 고객은 대출이자를 싸게 제공받을 수 있으며, 예금이자, 신용대출한도, 각종 수수 료, 환전 등에서 여러 가지 혜택을 누릴 수 있
다. 단순히 예치금액만을 가지고 기여도 평가를 한 결과와는 달리 다른 금융서비스 분야에서의 기여도를 함께 고려함으로써 토탈금융서비스를 실현할 수 있을 것이다.

세번째는 혜택 자동변경 및 선택을 도입하 는 것이다. 기본적인 혜택들은 유지하되, 연령 대 별로 플러스 혜택이 제공되고 이 혜택들은 나이대가 변경되면 자동으로 변경될 수 있도록 함으로써 장기고객 유치를 위해 노력해야 한다. 나아가 고객 스스로가 혜택이 정해져 있는 카 드를 선택하는 것이 아니라, 자신이 원하는 혜 택을 최대 몇 가지 정하여 자신에게 맞는 카드 를 이용하도록 하는 것도 고객유치와 유지에 효과적일 것이다.

\section{참고문헌}

안광호, 하영원, 박흥수, 마케팅원론, 학현사, 2010. Kevin Lane Keller, Conceptualizing, Measuring, and Managing Customer-Based Equity, Journal of Marketing, January 1992, pp. $1-22$

Prakash Nedungadi, Recall and Consumer Consideration Sets: Influencing Choice Without Altering Brand Evaluations, Journal of Consumer Research, December 1990, pp. 263-276

A. J. Silk and G. L. Urban, Pre-Test-Market Evaluation of New Packaged Goods: A Model and Measurement Methodology, Journal of Marketing Research, 15(2), May 
1978, pp.171-191

H. E. Krugman, Why Three Exposures May Be Enough, Journal of Advertising Research, 12(1972), pp.11-14

Allan Paivio, Mental Imagery in Associative Learning and Memory, Psychological Review, May 1969, pp.241-263

Kathy A. Lutz and Richard J. Lutz, The Effect of Interactive Imagery on Learning:
Application to Advertising, Journal of Applied Psychology, August 1977, pp.493-498 이학식, 안광호, 하영원, 소비자행동, 법문사, 2010. Kevin Lane Keller, Memory Factors in $\mathrm{Ad}^{-}$ vertising Evaluations, Journal of Consumer Research, Dec. 1987, pp.316-333 신한카드 브랜드활동, 신한카드 내부자료, 2011 광고캠페인변화추이, 신한카드 내부자료, 2011 


\title{
IMC Strategy of Sinhan Card for Building the Strong Brand Equity
}

\author{
Ahn, Kwang $\mathrm{Ho}^{*}$ \\ Yoo, Chang Jo** \\ Park, Woon Yong***
}

\begin{abstract}
Brand is the major enduring asset of a company and more valuable than the totality of specific products and facilities. Thus brands are powerful assets that must be carefully developed and managed. The company should design and implement marketing activities and marketing communication programs to build and grow the brand value. Strarbucks, Samsung Galaxy, and Nike brands get a price premium and generate strong customer loyalty.

A power brand has high brand equity, which is the differential effect that brand knowledge has on consumer response to the marketing of that brand. Brand equity is created when brands have strong, favorable and unique brand associations with customers and high level of brand awareness. Therefore marketers in building a strong brand should ensure to develop the right type of customer experiences with products and effective integrated marketing communication(IMC) programs to create the brand equity.

Since 2007 Sinhan card acquiring the LG card has developed the new brand identity and carefully managed the advertising campaign and other marketing communication mix tools to create the high brand awareness and differential brand image. In this case study we examine how Sinhan card with the goal of being No.1 brand in the credit card market has developed and implemented the IMC Strategy to build a high level of consumer brand awareness, unique brand image and strong customer relationship.
\end{abstract}

Key words: Brand awareness, Brand image, Brand equity, Customer equity, IMC.

\footnotetext{
* Professor, College of Business Administration, Inha University

** Professor, College of Business Administration, Dongguk University

*** Ph. D. College of Business Administration, Inha University
} 